\title{
MEMORIZING THE QUR'AN AS BANJARESE BRIDE-PRICE (A STUDY OF LIVING QURAN AND HADITH)
}

\author{
Munirah \\ Sekolah Tinggi Agama Islam Rakha Amuntai \\ Email: munirahelbanany@gmail.com
}

\begin{abstract}
One example of the living Qur'an and hadith are found in South Borneo. Living Qur'an and hadith refers to various ways in which this scriptures are practiced in Muslim daily live. In South Borneo, this deals with the phenomenon of memorizing the Qur'an as a bride-price (jujuran) for marriage among the Banjarese people. This tradition has been practiced for various reasons. Using phenomenological method, this study records the views of the people peforming this tradition and attempts to explain its practice and meaning. This study reveals that jujuran is an acculturation of the Qur'an with the local tradition. The people believe in the power of the Qur'an and make this to bless their important life cycle, such as marriage. The jujuran reflects various reasons, ranging from groom's seriousness to memorize the Qur'an and to marry and the best award for brides. However, most do not know the authoritative tradition from the Prophet regarding the bride-price of memorizing the Qur'an but are inspired by popular literature and novel that contain stories of the Qur'an as bride-price.
\end{abstract}

Keyword: Memorizing al-Qur'an, Jujuran, Banjarese, Living alQur'an and Hadith

DOI: http://dx.doi.org/10.20414/ujis.v21i2.319

\section{Introduction}

THE QUR'AN occupies important position in Muslim community. Not only do Muslims read this scripture to get reward from God and understand its meaning, but also attempt to internalize its teaching into their lives. The practice to make the Qur'an as living text has been existed since the Prophet Muhammad time. Among 
the examples is using of the first chapter of the Qur'an, al-Fātihah (the opening), to cure the disease, or the verse al-Mu'awwidhatayn (the human and the dawn) as repellent magic. ${ }^{1}$ This practice continues from time to time, even after Islam has reached areas beyond its mainland in Middle East. Indonesia is not an exception.

In Indonesia, the Qur'anic practices are mixed with the social culture and local tradition. ${ }^{2}$ Muslims use verses of the Qur'an to cure magic or make them as amulet to treat disease and spell genes. ${ }^{3}$ In the study of Qur'an, such practices are classified as living Qur'an. ${ }^{4}$ It is defined as study or scientific research about various social events that are related to the implementation of the Qur'an in Muslim communities. ${ }^{5}$ Living Qur'an is the text of the Qur'an which lives in a particular Muslim community.

In addition the Qur'an, such research or study also focuses on hadith since it is also Islamic scripture and a second to the Qur'an

${ }^{1}$ M. Mansur, "Living Qur'an dalam Lintasan Sejarah Studi a-Qur'an," in Metodologi Penelitian Living Qur'an dan Hadis, ed. Sahiron Syamsuddin (Yogyakarta: Teras, 2007), 3; On the other study of the power of the Qur'an, see, for example, Travis Zadeh, "Fire CannotHarm It: Mediation, Temptation and the Charismatic Power of the Qur'an," Journal of Quranic Studies 10, no. 2 (November 2009): 50-72.

2 See for example, Anne Rasmussen, Women, the Recited Qur'an and Islamic Music in Indonesia (Berkeley and Los Angeles: University of California Press, 2010).

3 Alfianoor, "Fragmen Ayat al-Qur'an dalam Mantra Masyarakat Banjar Kalimantan Selatan (Studi Kasus di Kabupaten Hulu Sungai Tengah)" (Undergraduate Thesis, Universitas Islam Negeri Sunan Kalijaga Yogyakarta, 2008).

${ }_{4}^{4}$ Broadly speaking, the genre and the object of Qur'anic study can be divided into five parts. First, the research put a textQur'an as the object of study (Dirāsat mā fì $a$-naș) with various methods and approaches and objectives, which vary according to the area of expertise readers. Second, the study put things out of text Qur'an, but is closely related to its emergence, as the object of study (Dirāsāt mā hawl al-Qur'an) as the study of asbāb al-nuzūl, historical writing and codifying text. Third, the research has made understanding the text Qur'an as a research objects. Fourth, research that focuses on community response of Qur'anic text and the results of one's own interpretation. A more complete view, read Sahiron Syamsuddin, Metodologi Penelitian Living Qur'an dan Hadis, ed. Sahiron Syamsuddin (Yogyakarta: Teras, 2007), xi-xiv.

${ }^{5}$ Mansur, "Living Qur'an," 8. 
in terms of its status as the source of Islam and Islamic law. ${ }^{6}$ The hadith or Sunna also becomes a source of Muslim living local tradition. This status of hadith is as the second source of Islam is emphasized in the various places in the Qur'an. Muslims attempt to replicate the models given by the Prophet. In the study of hadith, an attempt to explain the way in which hadith is practiced is called the living hadith. ${ }^{7}$

From the explanation above, the meaning of living Qur' an and hadith is the social events related with the existence of the Qur'an and Hadith in the empirical social life. This article will explain one example of the living Qur'an and hadith among Banjar communities (Banjarese). This deals with jujuran (bride-price) with memorizing the Qur'an paid by the groom as a gift to the bride when they get married.

This phenomenon can be labeled as living Qur'an because it reflects how the Qur'an is lived with the Muslims. Its memorization serves as a bride-price. But at the same time, this phenomenon can also be classified as living hadith because it is based on the tradition originated from the Prophet Muhammad's time where a companion paid his wife bride-price with his ability of memorization of the Quran instead of money or other materials. The current practice of jujuran is, therefore, grounded in this tradition. In order to avoid methodological biases and to keep focused, this study limits its scope only amongst the Banjarese society since bride-price by means of the Qur'an memorization is very popular in this society. ${ }^{8}$

In this study, I will analyze the jujuran from the phenomenological perpsective. It is scientific study that

${ }^{6}$ Zafar Ishaq Ansari, "The Contribution of the Qur'an and the Prophet to the Development of Islamic Fiqh," Journal of Islamic Studies 3, no. 1 (July 1992): 141171.

${ }^{7}$ On the example of the study of 'living hadith", see Sabine Damir-Geilsdorf and Mira Menzfeld, "Looking at the Life of the Prophet and How He Dealt with All the Issues: Self Positioning, Demarcations, and Belongingness of German Salafis from an Emic Perspective," Contemporary Islam 10, no. 3 (September 2016): 433-454.

8 Faris Keblawi, "Memorisation of the Quran: Opening the Research Agenda," Journal of Qur'anic Studies 16, no. 2 (July 2014): 168-195. 
approaches thoughts, ideas, emotions, experiences and so on from someone who have been seen through words and acts. ${ }^{9}$ By using this approach, the data is collected from the people who have experiences in memorizing the Qur'an and use this as their brideprice. For a thorough analysis, I will use mood and emotions theory proposed by Anna M. Gade when studying the Qur'anic recitation contest (musābaqah tilāwah al-Qur'ān) in Indonesian. This theory enables this study to explore what motivates the event and why this happens in the society. ${ }^{10}$

\section{The Qur'an Memorization as a Bride-price: A Common Reality}

Actually, the bride-price with memorizing Qur' an is not a new phenomenon. If we study Islamic history, in the Prophet's time, this phenomenon occurred. On one occasion, the Prophet officiated his best friend's marriage to a woman with a bride-price in the form of memorization of the Qur'an. However, during the next period until $t \bar{a} b i^{\prime} \bar{i} n$, the same narrative has not been found these times. It is rarely mentioned in al-Tārïkh al-Kabìr by Imām alBukhārī, al-Ișābah fī Tamyìz al-Sahābah by Ibn Ḥajar al-'Asqalānī, and so on. ${ }^{11}$ This seems to be a common pattern of historical report where bride-price in the form of memorizing the Qur'an is not mentioned in most referred literature of Islamic history. ${ }^{12}$

9 Imam Suprayogo and Tobroni, Metodologi Penelitian Sosial-Agama (Bandung: Remaja Rosdakarya, 2003), 103.

${ }^{10}$ Read further in Anna M. Gade, Perfection of Practice (Hawai: University of Hawai Press, 2004), 5-6; This theory followed religion concept of Geertz, that is (1) A system of symbols which act to (2) establish powerful, pervasive, and long lasting mood and motivations in men (3) formua te conceptions of a general order of existence and (4) clothing the se conceptions which such an aura of factuality (5) the moods and motivations seem uniquely realistic. Nur Rohman, "Anna M. Gade dan MTQ di Indonesia: Sebuah Kajian Metodologis," Al-A'raf: Jurnal Pemikiran Islam dan Fisafat 13, no. 1 (June 2016): 115.

11 The author also read on other history books via Maktabah Syamilah application

12 The author also checked it in the history books contained in the software Maktabah Syamilah using keywords os, but found none of these books that provide information about the practice of bride-price with memorization of the qur'an. Among the se books are al-Milal wa al-Nihal, 'Uyūn a-Akhbār, al-Kāmil fì alTārikh, al-Muntazìm,' Ajā'ib al-Asar, and many others. 
I thus turn to books of fiqh, but there is no any information about the practice. Some just talk little about the law and controversion like in Fath al-Wahhāb (the Shāfi'i fiqh) and al-Iqna' (the Hanbali fiqh), ${ }^{13}$ while I'anah Al-Talibin (the Shafi'i fiqh) did not discuss this matter. ${ }^{14}$ As in the book Bidāyah al-Mujtahid wa Nihāyah al-Muqtasid (Mālikī fiqh) by Ibn Rushd, it was mentioned a hadith about bride-price by means of Qur'an memorization. In that book, he discussed this issue deeper. ${ }^{15}$ I find the information of the practice of bride-price with Qur' an memorization at the end of the 20th century only in Egypt. Interestingly enough, the practice is conducted by Indonesian Muslims who get married there. ${ }^{16}$

In Indonesia, the practice of bride-price with Qur'an memorization began to bloom in recent years. For example, in the STEI SEBI area, there are at least five people that I know having married with that kind of bride-price. ${ }^{17}$ In Sumatra, there is also the practice of bride-price by the recitation of the Qur'an. Some time ago there was one person who did it. ${ }^{18}$ However, it is very difficult to reassure when this tradition initially begin in Indonesia. The only available explanation from some literature is concerned with the textual basis or the theory of bride-price with Qur'an memorization, not about the practice. ${ }^{19}$

Likewise in Banjar, there is no data about the beginning of this practice. In the books of figh Banjar, this practice is also not mentioned. The Kitab al-Sabill al-Muhtadin authored by Sheikh Arsyad al-Banjari, the primary fiqh reference of Banjarese, there is no discussions about the bride-price with memorizing the Qur'an.

${ }^{13}$ Ibn Rushd, Bidāyah al-Mujtahid wa Nihāyah al-Muqtașid (Lebanon: Dār alKutub al-'Ilmiyyah, 2010) Juz' 2: 16; Fathul Waḥhab, Juz' 2: 102: al-Iqnā' Juz' 2: 87 in Maktabah Syamilah application.

${ }^{14}$ Abū Bakr 'Uthmān ibn Muḥammad Shaț̣ā al-Dimyāṭi', I'ānah al-Ṭālibìn (Beirut: Dār al-Kutub al-'Ilmiyyah, 2013) Juz 3: 578-616.

${ }^{15}$ Ibn Rushd, Bidāyah al-Mujtahid, 450.

${ }^{16}$ Interview with $\mathrm{UH}$, the alumnus from al-Azhar University, February 20th 2017

${ }^{17}$ Interview with ML, January 5th, 2017

${ }_{18}$ Interview with IK, February 26th, 2017

${ }_{19}$ M. Thalib, Perkawinan Menurut Islam (Surabaya: Al-Ikhlas, 1993), 21-22; Sukris Sarmadi, Format hukum Perkawinan: dalam Hukum Perdata Islam di Indonesia (Yogyakarta: Pustaka Prima, 2009), 44. 
In addition, in his work entitled Bāb al-Nikāh, which discusses marriage and divorce, the discussion on it is not found either. ${ }^{20}$ However, I luckily found the information that some Banjarese has practiced it. His name is $\mathrm{H}$. Asnawi bin Abdullah, the Banjarese who has lived in Mecca and studied for 30 years there. Another person is a man who was born in 1900. He married a woman with a dower of reciting al-Fātihah. But, according to the information, the marriage took place in Mecca. ${ }^{21}$

\section{Jujuran in Banjarese Tradition}

Jujuran

Jujuran literally means bride-price. ${ }^{22}$ It is amount of money that must be given by the groom or his family to the bride or her family. The money may be used to fund the wedding ceremony (walimah). According to Tichelman, in Barabai, jujuran is as the replacement part for bride's parent because they have educated the woman. By paying jujuran, the bride's parent must leave their right at bride. This opinion still applies but the bride-price does not divide bride's family anymore as like Tichelman's words. In addition, it is used for bride's needs herself like buying the wedding dress, furniture, or for walimah. ${ }^{23}$

The gift like jujuran had existed in Arabia pre-Islamic era, long time before Islam came. That award is not given to bride, but to father's bride or close family of the wife, because the concept of marriage according to the tradition at that time was same as sale and purchase transactions: buying and selling between the groom as a buyer and the father or close family of the bride as the owner of the good. When Islam came, the concept of this provision was

20 See Muhammad Arsyad al-Banjari, Sabìl Al-Muhtadīn Disalin Oleh M. Asywadi Syukur Ke Dalam Bahasa Indonesia. Surabaya: Bina Ilmu. Tt, n.d.; Muhammad Arsyad al-Banjari, Al-Banjari, Muhammad Arsyad. 1997. Luqtah Al'Ajalan. Martapura: Yayasan Pendidikan Islam Dalam Pagar., n.d.

${ }^{21}$ The result of interview with RA, the third generation of $\mathrm{H}$. Asnawi, 25 February 2017

22 Team, Kamus Bahasa banjar Dialek Hulu-Indonesia (Banjarbaru: BalaiBahasa Banjarmasin, 2008), 70.

${ }^{23}$ Alfani Daud, Islam dan Masyarakat Banjar: Deskripsi dan Analisa Kebudayaan Banjar (Jakarta: Grafindo Persada, 1997), 89. 
replaced. If it was previously paid to the father of bride then it turned into a gift given for the bride herself. Thus, the Qur'an changed the status of women as a "commodity" to be a subject that participated in the contract. ${ }^{24}$ While jujuran in Banjar society is often given to the parent of the bride, but on its use, the jujuran is also used for the purposes of the bride, for example to buy equipment for a wedding or other else.

In the past, all of jujuran mentioned in aqad (marriage contract) like a bride-price. But now, some Banjareses just mention a part of jujuran in 'aqad and even other things as the bride-price. The outstanding is only a gift. For example, the jujuran is $\mathrm{Rp} 150.000,00$ but the bride-price mentioned in 'aqad is only $R p 4.500,00$ or a Holy Qur'an. ${ }^{25}$ On its way, jujuran tradition in Banjarese has changed. In the majority of Banjarese's mind, mahar and jujuran are two different things. The bride-price is amount of money or thing (e.g, jewelry, a set of prayer equipment, etc.) that mentioned in 'aqad. Meanwhile, jujuran is an amount of money or valuable objects (outside bride-price) given by the groom as a gift or award to bride without being mentioned in the 'aqad.

Public's understanding of the Banjarese about bride-price and jujuran have been amended as before. But one thing has not changed. Jujuran is a bound gift although is not mandatory with amount agreed by both parties after they decided to get married. That is, the groom must give something (usually sum of money) to bride before the wedding outside administration as a bride-price. Thus, the bride-price and jujuran are different in terms of religion. But in fact, both are the same thing for Banjarese, which is equally obligatory.

The value of jujuran is counted on several things such as the background of the bride. The more famous and respectable family of the bride, the more the higher is her jujuran. In addition, jujuran also relates to the level of beauty of the bride, the more beautiful the woman, the more the higher is her jujuran. For this moment, the main factor which affects the amount of jujuran is the

${ }^{24}$ Nasaruddin Umar, Kodrat Perempuan dalam Islam (Jakarta: Lembaga Kajian Agama dan Gender, 1999), 25.

${ }^{25}$ Daud, Islam dan Masyarakat, 89-90, 196. 
educational level of the woman. Today, many Banjarese women have high education and hold a prospective career. Education and career status of the bride thus determine most the amount of jujuran. The higher education and career a woman has, the higher the jujuran will be proposed.

In its later development, jujuran also has changed regarding the content. It is not limited to money, items, or services but people begin to use the memorization of the Qur'an as jujuran, either overall or certain aspect of it, either as mahar that is mentioned in marriage contract or gift outside mahar given by the groom to the bride without mentioning in the marriage contract. It is not known exactly when this changing phenomenon of jujuran by memorizing the Qur'an started to happen among the Banjarese. Roughly, this started blooming in the last 4 or 5 years.

\section{Banjarese and the religious practices}

Banjarese are known as devout to their religion. Although it is difficult to prove statistically, on average only few are not practicing their religion. The Banjarese like to build langgar (place to pray for Muslims, a small mosque) where they pray together every day especially the night pray during Ramadhan. The people who come and pray in the langgar significantly increased. Likewise, the other religious activities carried out by Banjarese enthusiastically. ${ }^{26}$

The appreciation of Banjarese to the Qur'an is very high. Ulama Banjar (Banjar Muslim scholars) always advise people to read the Qur'an. Arabic is deemed by Banjarese to have a karāmah (spiritual power) because the Arabic letters are from the Qur'an. The verses of the Qur'an in Arabic are then believed to have the capability to deter supernatural attacks. That belief makes the Qur'an has more excess than mantra (spell). ${ }^{27}$ Thus, rhyme and spells use the verses of the Qur'an. Below is the example of spell derived from the Qur'an.

Iyyaaka a'budu

${ }^{26}$ Ibid., 7.

27 Yusliani Noor, Islamisasi Banjarmasin Abad ke-15 sampai ke-19 (Yogyakarta: Ombak, 2016), 413-414. 
Iyyaka nasta'in

Hatinya bodo

Matanya kada kalian

The meaning and usefulness of the mantra above is to make someone we like not change his/her heart to others. It is expected that his/her heart will be closed to others but belong to a certain person alone. ${ }^{28}$

We also can see the enthusiastic of Banjarese to memorize the Qur'an; many Banjarese bind up in this. It is evident with the emergence of many institutions for memorizing (tahfiz) al-Quran, scattering in many places in the region of South Borneo. Memorizing the Qur'an among the Muslim community has been a tradition since the time of the Prophet Muhammad. Moreover, the Qur'an and hadith were in the first time delivered orally, demanding strong memorization ability. When the Qur'an has been codified, memorizing culture is maintained until now.

In Banjar, there are many institutions or boarding schools that train haffiz (the male who is able to memorize the Qur'an) and hafizah (the female) of various ages, from the young to adult. Muslims who memorize the Qur'an is believed to get a high position, both in this world and in hereafter. ${ }^{29}$ One example is found in Antasari State Islamic University. There are at least three tahfiz institutions. In Amuntai, there is a Sekolah Tinggi Ilmu alQur'an (STIQ) where all of its students must be able memorize the Qur'an.

\section{Motivation of the Jujuran}

The practice of jujuran with Qur'an memorization is actually still based on the former tradition inherited from the Prophetic practice. The main bride-price is any materials like money or a set of praying equipment, etc. However, recently it changed and included the memorization of Qur'an as a bride-price beside the others. One informant said:

28 Alfianoor, "Fragmen Ayat," 47.

${ }^{29}$ It is based on the Hadith "Verily Allah exalt including respect for the elderly a re Muslims, memorize rof Qur'an that do not exceed the limit (in practice and understand it) and not away from it (reluctantly read and practice it) and Ruler fair." (HR. Abu Daud) 
Pada awalnya saya meminta mahar hafalan al-Qur'an saja. Tetapi pihak keluarga kurang setuju, kata kakek saya kalau calon suamimu mampu memberikan mahar yang lain kenapa tidak? Bahkankata nabi walau dengan mahar cincin dari besi atau sepasang sendal. Setelah terjadi perdebatan-perdebatan, akhirnya diputuskan maharnya hafalan a-Qur'an ditambah seperangkat alat shalat dan seperangkat berlian." 30

"At first time, I just asked the memorization of the Qur'an as my mahar. But my family does not agree, my grandfather said that your future husband is able to provide mahar else, why not? Even the Prophet said from a ring of iron or a pair of sandals (can be counted as mahar). After the debates, it was decided my maharare the memorization of the Qur'an plus a set of praying equipment and a set of diamonds."

This statement shows us that the jujuran of memorization of the Qur'an is debatable among Banjarese. To mediate the difference, the bride-price is not only memorization of the Qur'an but also equipped with something valuable. Similarly, a male informant, FA, said that the bride-price to his bride is not only memorization of the Qur'an but also money and jewels in order not to cause any controversy. The memorization of Qur'an is only an option. ${ }^{31}$ The same views are voiced by other informants.

This phenomenon comes from a desire that the Qur'an, a holy book, can be a witness for their wedding day. They see that marriage is a holy moment, so it must have something very valuable, that is the Qur'an. FA said, he wanted a tabarrukan (get blessing) from memorizing the Qur'an in his bride-price and his marriage..$^{32}$ This conscious thought is based from his condition and his education as an alumnus of al-Azhar University, Egypt. So, the other informants who had the memorization of the Qur' an as the additional bride-price have similar background on ta hfiz al-Qur'ān.

Meanwhile, MRH, another informant, explained that his wife's wished to have memorization of the Qur' an as the bride-price. She started after reading a book which describes about virtue of sürah al-Rahmōn as a mahar. The book is Ku Pinang Kau dengan Sürah alRahmmān: Mahar Cinta dari Sang Maha Cinta. ${ }^{33}$ So, he gave memorizing the Qur' an as his jujuran to his wife, RA. She wanted

\footnotetext{
${ }^{30}$ Interwiew with ML, January 5th, 2017

${ }^{31}$ Interview with FA, February 25th, 2017

32 Interview with FA, February 25th, 2017

${ }^{33}$ Intervie w with MRH, January 8th, 2017
} 
to have the Sürah al-Rahmān as her mahar after reading a novel by Asma Nadia. As she said:

"Initially, after reading the novel by Asma Nadia (I wanted memorizing Quran as my jujuran), but I forgot what the title of that novel. That is all, no other reason. When I read it, I thought to myself, I'll also want that marriage mahar with sūrah al-Rahmmān. So, when I get married, I stated my wish, then my husband agreed". ${ }^{34}$

Another informant named AR presented Sūrah al-Insān as a bride-price for his wife because he is inspired by his brother, who was preparing the memorization of Sūrah al-Rahmmān as his mahar. ${ }^{35}$

From the explanations of the informants above, their brideprice with memorization of the Qur'an is an acculturation. There is an effort to make the jujuran tradition as a Qur'anization without changing it. Qur'anization in this phenomenon can be called as a living Qur'an as indicated by Ahimsa. This includes the integration of the Qur'an into all aspects of human life, or makes human life as an arena to manifest the Qur'an on the earth. ${ }^{36}$

As described in the foregoing discussion, Banjarese have high respects for the Qur'an and glorify it. The Qur'an in this phenomenon is interpreted as a special book not an ordinary book because it contains the words of God which was revealed through the Gabriel, through certain signs, and so on. God is the Essence of Glory. Therefore, the His words is holy too. Likewise marriage, it is a holy promise (mîthāqan ghalizzā) between a couple. Marriage requires the holy witness too, i.e. memorization of the Qur'an.

Behind this phenomenon, there are motivations from the informants for doing this. One of them is ML. She said:

"Awalnya karena memang sebelum menikah ada keinginan dan cita-cita mendapatkan suami yang hafal al-Qur'an supaya dapat menjag a hafalan saya. Saya but uh seseorang yang benar-benar keras dalam menjaga hafalannya. Sebab yang namanya menjaga hafalan itu sangat susah, perlu lingkungan yang selalu

${ }^{34}$ Interview with RA, January 12th, 2017

${ }^{35}$ Intervie w with RA, January 12th, 2017

${ }^{36}$ Heddy Shri Ahimsa-Putra, "The Living al-Qur'an: Beberapa Perspektif Antropologis," Walisongo: Jurnal Penelitian Sosial Keagamaan 20, no. 1 (May 30, 2012): 251. 
mendukung. Jika tidak, maka saya tidak tau bagaimana nasib hafalan saya selanjutnya. Karena itu saya selalu berdo'a kepada Allah supaya mengabulkan keinginan saya ini. Jadi, waktu itu ada beberapa orang yang ingin ta'aruf. Untuk menguji keseriusan mereka, saya tantang siapa yang siap dan sanggup menikahi saya dengan mahar hafalan al-Qur'an 30 juz'. Dua orang di antaranya menyatakan kesang gupannya, salah satunya suami saya sekarang. Singkat cerita, dari dua orang ini saya coba shalat ist ikhārah beberapa kali dan mempertimbangkan berbagai hal hingga akhirnya terpilihah suami saya sekarang ini dan menikah dengan mahar hafalan 30 juz' seperti yang saya inginkan."37

"At the first time, before I get married there is a will to find a husband who is able to memorize the Qur'an, so he can keep my memorization. I need someone who is really hard on maintaining his memorization, because keeping memorization of the Qur'an is uneasy: it needs an supporting environment. If not, I do not know what will happen to my memorization. So, I always pray to God to grant me this wish. So, at that time there are some people who want ta'aruf (Introduction session before deciding to get married). To test their seriousness, I challenge them who is ready and able to marry me with a bride-price, memorizing 30 juz' of the Qur'an. Two of them expressed their willingness, one is my husband now. In short, from these two people I had istikhārah (Pray to askhint from the God) for several times and consider various things until finally I chose my husband now and married with a mahar memorizing 30 juz' as I wish." 38

From the first informant above, it can be seen that the motivation for selection of memorizing Qur'an as a mahar is to test the seriousness of the groom. Mahar in this one is a challenge given by women to men to know how much their seriousness to marry is. In addition, the most important motivation of the explanation is the desire of the informants to create a Qur'anic family and always keep the memorization of the Qur'an consistently. As her opinion, the environment is a major factor in keeping the memorization of the Qur'an.

In the tone, $\mathrm{R}$, another informant, also made the memorization of the Qur'an to test the seriousness of her husband. She explained that:

"Dari isyarat-isyarat hati yang mendukung ke arah sana. Awalnya untuk meyakinkan hati, apabila mau menyang gupi persyaratan berarti jodoh. Setiap kali istikhārah yang terlintas adalah surat al-Raḥmān. Setelah syarat dipenuhi, ulun mimpi mancari al-Qur'an yang biasa ulun pakai, ternyata singkat cerita ulun

${ }^{37}$ Interview with ML, January 5th, 2017

${ }^{38}$ Interview with ML, January 5th, 2017 
menemukan sebuah mesjid di dalamnya ada satu urang mangaji Qur'an yang ulun cari, ternyata urang tersebut calon suami"39

"(it comes) From the signal of heart that supported me to do it. At the first is to convince my heart, if he agreed, it means that he is my mate. Whenever I pray istikhārah (seeking God's guidance), it comes Sūrah al-Rahmān. After the term fulfilled, I have a dream, I am looking for my muṣhaf that I am used to reading, then I find a mosque where someone read by using my muṣhaf, he is my husband candidate." 40

This motivation refers to a hadith which explain the criteria to choose groom or bride at the first priority is from his or her piety. ${ }^{41}$ Moreover from his or her skill in the Qur'an recitation, better one is those who hold Qur'an memorization. Because the haffiz or $h \bar{a} f i z a h$ has a high religious position as the Prophet said. It is narrated from Anas bin Mālik. He said that Rasulullah said, "In truth, Allah has family from the human. He asked: who are they oh Rasulullah? He said, ahl al-Qur'ān is Allah's family and the elite people." 42

The other motivation for making memorization of the Qur'an as the best award for the bride-price is explained by MRH. He memorized the Qur'an as jujuran because his prospective wife wanted to have a soul mate who can memorize sürah al-Rahmmān when the marriage contract took place. So, his motivation is to grant her prospective wife's wish. He said, "the mahar is an appreciation to women in marriage. My wife pleased sürah alRahmān as her bride-price than the other expensive things or materials. ${ }^{43}$

${ }^{39}$ Interview with $\mathrm{RH}$, January 8th, 2017

${ }^{40}$ Interview with $\mathrm{RH}$, January 8th, 2017

41 The hadith is

عن أبي هربرة عن النبي صلى الله عليه و سلم قال : تنكح المرأة لأريع لمالها ولحسبها ولجمالها ولدينها

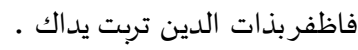

Abū al-Ḥusayn 'Asākir al-Dīn Muslim ibn al-Ḥajjājibn Muslim ibn Ward ibn Kawshādh al-Qushayrī al-Naysābūrī, Ṣaḥ̄h Muslim, Juz' 2 (Beirut: Dār Ihyā' alTurath al-'Arab, n.d.), 1086.

42 Abū 'Abdillāh Muhammad ibn Yazīd al-Rab‘ī al-Qazwīn̄i Ibn Mājah, Sunan Ibn Mājah, Juz' 1 (Beirut: Dār al-Fikr, n.d.), 78.

${ }^{43}$ Intervie w with MRH, January 8th, 2017 


\section{Living Hadith in the Phenomenon of Banjarese's Jujuran}

The tradition of using memorization of the Qur'an as a brideprice has actually happened in time of The Prophet Muhammad as described in Șah̄inh al-Bukhārī hadīth no. $4799^{44}$

Qutaibah told us, Abdul Aziz bin Abi Hazim told us from Sahl ibn Sa'd alSa'idi, he said, a woman came to Prophet and said: "O Rasulullah, that I have come to give myself to you. So, the Prophet was looking at her from top to bottom and vice versa, then he nodded. When the woman realized that the Prophet did not give any decision to him, then he sat down. Then a friend stood up and said: "O Messenger of Allah! If you do not want her, marry me with her". The Prophet asks: "Do you have anything to be used as a brideprice?", "No, by God, O Messenger of God," he said, "Go to your family, you might look to get something," pleaded the Prophet saw. The man went a way, not long he was back, "By Allah, I did not get anything," he said. Prophet saw said: "Look, although only in the form of an iron ring." The man went a gain later, before long time he was back, "By Allah, O Messenger of Allah! I do not get a ring of iron, but this was my glove, half of it to this woman." "What can you do with your sheath? If you wear it, that meant she did not get the glove. And if she wears it, that means you do not wear gloves. "The man was sitting up. When he seated for a while, he rose. Prophet saw turned away, then he ordered someone to call the men. When he was in front of the Prophet, he asked, "What have you memorized from Al-Qur'an?" "I memorized this verse and sūrah," he answered. "Really you memorize it in your heart?," said the Prophet. "Yes," he replied. "If so, well, really I have married you with this lady with a bride-price in the form of Al-Qur'an verses that you memorize," said the Prophet saw."

The hadith explains that the Prophet officiated a marriage of his companion with the woman where recitation and memorization of a verse of the Qur'an serves as a bride-price. In another hadith, the Prophet asked a friend to get married with memorizing the letters of the Qur'an as bride-price. It was explained in the following hadith. ${ }^{45}$

Abdullah said, my father told me that 'Abdullāh bin al-Harith said Salamah bin Wardan told me that Anas bin Mālik companions of the Prophet told that the Holy Prophet said to a man from his friend, "O șahabah, have you got married?" He replied, "not yet, I do not have anything that could be used as a bride-price for the wedding". The Prophet said, "Did not you have rote

${ }^{44} \mathrm{Abū}$ 'Abd Allāh Muhammad ibn Ismā'îl ibn Ibrāhīm ibn al-Mughīrah ibn Bardizbah al-Ju'fī al-Bukhārī, Sahịh Al-Bukhārī, vol. 1, Kitāb al-Wālah (Kairo: Dār al-Sha'b, n.d.), 1965.

45 Abū 'Abdullāh Aḥmad Ibn Ḥanbāl, Musnad Aḥmad ibn Hanbāl (Cairo, Egypt: Mu'assasah Qurțubah, n.d.) Juz 28, 188. 
ققل هو اللهأحد)", Well, yes the Prophet. The Prophet said, "It is like a quarter of قل يأيها

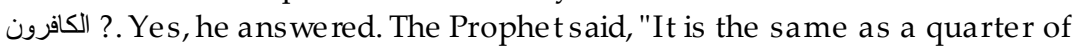
the Qur'an." The Prophet asked, "Do not you memorize إذا زلزلت الأرض letter?". He replied, "correct." The Prophet said, "It is the same as a quarter of the Qur'an". The Prophet then asked, "Do not you memorized sürah جإذاء نصر الله." He answered, "yes.. " The Prophet said, "It is the same as a quarter of the Qur'an ". Recently the prophet asked, "Do not you memorize Kursi verses? He replied, "yes." The Prophet said, "It is the same as a quarter of the Qur'an." Then he said, "marry, marry, marry." Repeated three times.

Two hadith above are foundation for some scholars in their argumentation to allow the use of the Qur'an memorization as a bride-price. In the Fath al-Barī, it is stated that in the history of $\mathrm{Ab} \overline{1}$ Umāmah, a bride-price is not just reading the Qur'an, but also teaching it. Likewise, it is mentioned that in the history of Abu Hurayrah, the Prophet ordered a man to teach 20 verses of sürah that he makes it as a bride-price. While in the narration of Ibn Mas'ūd said that the Prophet married the man with the verses of Qur' an and teach it. But, when God gives him a fortune, then he should replace that bride-price. This hadith shows that there is no minimum limit of the bride-price. So, it can be used to reject the argument that states the minimum of bride-price is a quarter of a dinar. ${ }^{46}$ In The $a l-A w n A l-M a{ }^{\prime} b \bar{u} d$, it is said that the hadith is a argumentation of the Qur'an that teaching can be a bride-price. If it not allowed, then The Prophet will not ask what friend had memorized of the Qur'an or no? ${ }^{47}$

Muslim scholars have different understanding of the hadith above, especially about the permissibility of using memorization of the Qur'an as a bride-price. In fact, the phenomenon is relief in the Muslim community in Indonesia today, particularly among the Banjarese. It shows the intention of the people to revive the Prophet traditions although sometimes the phenomena that happen in Banjarese is not exactly same as what is practiced in Prophet time.

46 Aḥmad ibn 'Alī Ibn Ḥajar al-Asqalānī, Fatḥ Al-Bārī Fì Sharh Șahịh AlBukhārī, vol. 10, n.d. Juz 1, 415.

${ }^{47}$ Muḥammad Shams al-Ḥaq Abū al-Ṭayyib, Al-'Awn Al-Ma'būd (Beirut: Dār alKutub al-'Ilmiyyah, 1415), 499. 
The difference of situation and location causes a shifting in the practice of the memorization of the Qur'an as a bride-price from the Prophet's time to the present day. If we observe thoroughly, the permission to use memorization as a bride-price in the hadith above caused by the companion's condition, who do not have materials or anything that can be used as a bride-price. But, for the Banjar society, they keep the tradition for several reasons or motivation. The majority of the informants of this study are rich enough so they can afford to give a bride-price in the form of properties, money or valuable object. This is why the bride-price given by informant to his wife is not just a recitation of the Qur'an, but also added with some money, a set of praying equipment, diamond, etc.

When asked, the informants gave various answers. ML explained that she did not know for sure about the tradition. ML explain more, "When I want mahar with memorization of the Qur'an, the reason is, in my opinion, that a woman is not goods that can be traded for money or objects as the prophet said that the best bride-price is the least. ${ }^{48}$ The hadith is

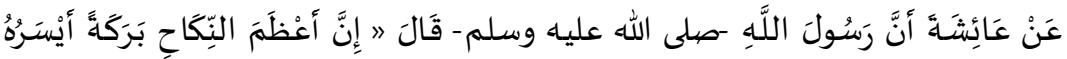

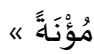

"From Aisya, Rasulullah said: in truly, the bigger blessing of marriage is the smaller cost"

The principles held by ML is in line with the message contained in the hadith above to organize the wedding in a simple way without worrying about the cost of an expensive mahar, just as much as her husband has. In addition, I found another tradition from informants who made the Qur'an as her bride-price. As RA answered when asked about his knowledge about that hadith,

"Iya pernah. Yang saya tahu dahulu ketika nabi ing in menikahkan sayyidah Fatimah, anak beliau. Nabi mengadakan sejenis sayembara, siapa yang berhasil mengkhatamkan membaca al-Qur'an dalam waktu semalam, maka akan dinikahkan dengan anaknya Fatimah. Dengan kecerdasannya, sayyidina Ali yang berhasil memenang kannya hanya dengan membaca surat al-Ikhlas sebanyaktiga kali. Karena sebelumnya nabi pernah bersabda, "barangsiapa yang membaca surat al-Ikhlas sebanyak tiga kali maka sama seperti membaca al-Qur'an seluruhnya 30 juz'.

${ }^{48}$ Interview with ML, January 5th, 2017 
Setelah it unabi pun menikahkan Fatimah dengan Ali dengan mahar surat al-Ikhlas sebanyak tiga kali tadi, it u yang saya tahu"49

"Yes I did. What I am aware is that when the Prophet wants to marry his daughter, Fatimah, to a man. The Prophet held a similar contest, saying who will be able to finish reading Qur'an in a night, he will be married him with Fatimah. With his intelligence, Sayyidina Ali who managed to win just reading sūrah al-Ikhlās three times. Because the Prophets once said, "He who read the letter of al-Ikhlās three times, it is as if he/she finishes reading the Qur'an wholly. After that the Prophet married Fatimah to Ali with a brideprice sürah al-Ikhlās. This is the story I know."

From the statement above, although RA does not know the origin of the tradition, she knows the other similar history of Ali and Fatimah. The historical account shows that the Prophet challenged his companion who wanted to marry Fatima by reciting the Qur'an completely overnight. The șhabah who could finish reading the Qur'an successfully would be married of with the Prophet daughter. This case in the Prophet's period reoccurs now, as revealed in the stories of by ML and $\mathrm{RH}$. Both challenged her husband if they were able to provide honesty with memorizing Qur'an 30 juz'.

I myself often hear the story of Ali and Fatimah above is reproduced by Muslim preachers in Banjar. However, I traced the source of the history in several books of hadith but to no avail. No reference about the tradition is mentioned in al-kutub sittah and alkutub al-tis'ah, and several other books of hadith. Also in the history books, the story of 'Alī ibn Abī Țālib and Fāṭimah al-Zahrā is rarely found. ${ }^{50}$

MRH said that the story in Ku Pinang Kau dengan Sürah alRahmōn; Mahar Cinta dari Sang Maha Cinta book inspired his wife to make Sūrah al-Rahmān as her mahar. There are various traditions relating to bride-price using memorization of the Qur'an as well as the primacy of sürah al-Rahmānn. ${ }^{51}$ It shows that they

${ }^{49}$ Interview with AR, January 12th, 2017

50 The history about Ali and Fatimah's marriage explained in some history books, see Muhammad Kāzim al-Qazwānī, Fātimah al-Zahrā' min al-Mahdi ila alLahdi (al-matba'ah al-'Ilmiyyah, 1414), 121-133; 'Alī Muha mmad al-Shalabī, Sìrah Amīr al-Mu'minīn 'Al̄̄ ibn Ab̄̄ Tạlib: Shakhsiyyatuhu wa 'Așruhu (Cairo, Egypt: Mu'assasah Iqra', 2005), 80-81.

${ }^{51}$ Intervie w with MRH, January 8th, 2017 
have known the story about the best companion of the Prophet who married with a bride-price memorizing the Qur'an.

\section{Conclusion}

There are several things that can be inferred from all explanation in this article. First, all of the informants have a background on memorizing (tahfīz) of the Qur'an. This is one inspiring factor of the jujuran tradition. Second, the inspiration of the jujuran with the Qur'an memorization in Banjar originates from the brides who want to make the Qur'an, a holy book, as a witness in their wedding day, although this is still be controversial among Banjarese. The jujuran tradition consists of not only the Qur'an memorization, but also some things valuable. The Qur'an memorization is one important aspect of the jujuran. The brides who asked their jujuran in the form of memorizing Qur'an got an inspiration from the popular novel. Third, this phenomenon is an acculturation that makes Qur'anization in the jujuran tradition. Fourth, the motivations of the jujuran vary. Some of them is to test the seriousness of groom, following the hadith to choose a groom or a bride at the first priority is from his or her piety. The other motivation is to make the memorization of Qur' an as a best award for bride. The brides wish to have a memorable bride-price that has spiritual and religious values, not simply objects which are easily gone away. Fifth, almost all of the informants do not know the hadith which states that Prophet Muhammad wedded his companion with memorizing Qur'an.

\section{References}

Abū al-Ṭayyib, Muḥammad Shams al-Haq. Al-'Awn Al-Ma'būd. Beirut: Dār al-Kutub al-'Ilmiyyah, 1415.

Ahimsa-Putra, Heddy Shri. "The Living al-Qur'an: Beberapa Perspektif Antropologis." Walisongo: Jurnal Penelitian Sosial Keagamaan 20, no. 1 (May 30, 2012): 235-260.

Alfianoor. "Fragmen Ayat al-Qur'an dalam Mantra Masyarakat Banjar Kalimantan Selatan (Studi Kasus di Kabupaten Hulu Sungai Tengah)." Undergraduate Thesis, Universitas Islam Negeri Sunan Kalijaga Yogyakarta, 2008. 
Ansari, Zafar Ishaq. “The Contribution of the Qur'an and the Prophet to the Development of Islamic Fiqh." Journal of Islamic Studies 3, no. 1 (July 1992): 141-171.

al-Asqalānī, Aḥmad ibn 'Alī Ibn Ḥajar. Fatḥ Al-Bārī Fī Sharh Ṣaḥīh Al-Bukhārī. Vol. 10, n.d.

al-Banjari, Muhammad Arsyad. Al-Banjari, Muhammad Arsyad. 1997. Luqtah Al-'Ajalan. Martapura: Yayasan Pendidikan Islam Dalam Pagar., n.d.

- - - Sabìl Al-Muhtadīn Disalin Oleh M. Asywadi Syukur Ke Dalam Bahasa Indonesia. Surabaya: Bina Ilmu. Tt, n.d.

al-Bukhārī, Abū 'Abd Allāh Muhammad ibn Ismā‘īl ibn Ibrāhīm ibn al-Mughīrah ibn Bardizbah al-Ju'fī. Șa hịh Al-Bukhārī. Vol. 1. Kitāb al-Wālah. Kairo: Dār al-Sha'b, n.d.

Damir-Geilsdorf, Sabine, and Mira Menzfeld. "Looking at the Life of the Prophet and How He Dealt with All the Issues: Self Positioning, Demarcations, and Belongingness of German Salafis from an Emic Perspective." Contemporary Islam 10, no. 3 (September 2016): 433-454.

Daud, Alfani. Islam dan Masyarakat Banjar: Deskripsi dan Analisa Kebudayaan Banjar. Jakarta: Grafindo Persada, 1997.

al-Dimyāț̣̂', Abū Bakr 'Uthmān ibn Muhammad Shaț̣ā. I'ānah alȚālibìn. Beirut: Dār al-Kutub al-'Ilmiyyah, 2013.

Gade, Anna M. Perfection of Practice. Hawai: University of Hawai Press, 2004.

Ibn Hanbāl, Abū 'Abdullāh Aḥmad. Musnad Aḥmad ibn Hanbāl. Cairo, Egypt: $M u^{\prime}$ assasah Qurțubah, n.d.

Ibn Mājah, Abū 'Abdillāh Muhammad ibn Yazīd al-Rab'ī alQazwīnī. Sunan Ibn Mājah. Juz' 1. Beirut: Dār al-Fikr, n.d.

Ibn Rushd. Bidāyah al-Mujtahid wa Nihāyah al-Muqtașid. Lebanon: Dār al-Kutub al-'Ilmiyyah, 2010.

Keblawi, Faris. "Memorisation of the Quran: Opening the Research Agenda." Journal of Qur'anic Studies 16, no. 2 (July 2014): 168-195.

Mansur, M. "Living Qur'an dalam Lintasan Sejarah Studi aQur'an." In Metodologi Penelitian Living Qur'an dan Hadis, edited by Sahiron Syamsuddin. Yogyakarta: Teras, 2007. 
al-Naysābūrī, Abū al-Ḥusayn 'Asākir al-Dīn Muslim ibn al-Hajjāj ibn Muslim ibn Ward ibn Kawshādh al-Qushayrī. Șaḥịh Muslim. Juz' 2. Beirut: Dār Ihyā' al-Turath al-'Arab, n.d.

Noor, Yusliani. Islamisasi Banjarmasin Abad ke-15 sampai ke-19. Yogyakarta: Ombak, 2016.

al-Qazwān̄̄, Muḥammad Kāzim. Fātimah al-Zahrā' min al-Mahdi ila al-Lahdi. al-matba'ah al-'Ilmiyyah, 1414.

Rasmussen, Anne. Women, the Recited Qur'an and Islamic Music in Indonesia. Berkeley and Los Angeles: University of California Press, 2010.

Rohman, Nur. "Anna M. Gade dan MTQ di Indonesia: Sebuah Kajian Metodologis." Al-A'raf: Jurnal Pemikiran Islam dan Fisafat 13, no. 1 (June 2016): 109-126.

Sarmadi, Sukris. Format hukum Perkawinan: dalam Hukum Perdata Islam di Indonesia. Yogyakarta: Pustaka Prima, 2009.

al-Shalabī, 'Alī Muhammad. Sīrah Amīr al-Mu'min̄̄n 'Alī ibn Abī

Tālib: Shakhsiyyatuhu wa 'Așruhu. Cairo, Egypt: Mu'assasah Iqra', 2005.

Suprayogo, Imam, and Tobroni. Metodologi Penelitian Sosial-Agama. Bandung: Remaja Rosdakarya, 2003.

Syamsuddin, Sahiron. Metodologi Penelitian Living Qur'an dan Hadis. Edited by Sahiron Syamsuddin. Yogyakarta: Teras, 2007.

Team. Kamus Bahasa banjar Dialek Hulu-Indonesia. Banjarbaru: Balai Bahasa Banjarmasin, 2008.

Thalib, M. Perkawinan Menurut Islam. Surabaya: Al-Ikhlas, 1993.

Umar, Nasaruddin. Kodrat Perempuan dalam Islam. Jakarta: Lembaga Kajian Agama dan Gender, 1999.

Zadeh, Travis. "Fire Cannot Harm It: Mediation, Temptation and the Charismatic Power of the Qur'an." Journal of Quranic Studies 10, no. 2 (November 2009): 50-72. 